\title{
Petrology of bebedourites from the Salitre phoscorite-carbonatite complex, Brazil
}

\author{
E. S. R. Barbosa, T. C. Junqueira-Brod, J. A. Brod and E. L. Dantas \\ Instituto de Geociencias, Universidade de Brasilia, Brazil (elisabarbosa@unb.br / Phone: +55 613307 2873)
}

The Late-Cretaceous Salitre complex, is one of a number of plutonic phoscorite-carbonatite complexes occurring in the the Alto Paranaíba Igneous Province (APIP), central Brazil, and is mainly composed of bebedourite, phoscorite, carbonatite, and syenite. The name bebedourite was proposed by Tröger (1928) to designate rocks with variable amounts of olivine, diopside, apatite, perovskite, magnetite, and phlogopite. Salitre is the type locality for bebedourite, but this rock-type is also dominant in other APIP complexes (e.g. Tapira), although in some cases (e.g. Araxá, Catalão) it has been extensively transformed in phlogopitite by late-stage carbonatitic metasomatism.

\section{Petrography}

Bebedourites are typically medium- to coarse-grained cumulate rocks, rarely occurring as fine-grained dykes or as pegmatoidal facies. The modal proportions of the essential constituents vary widely and rapidly in the cumulates, making it difficult to fit these rocks into conventional nomenclature schemes (e.g. Le Maitre et al., 2002). Igneous layering is relatively common and some samples display oriented fabric produced by crystal mush flow. Regardless of modal variations, the stability and textural relationships of the $\mathrm{Ca}-\mathrm{Ti}$ phases perovskite, titanite, and melanite is a key feature in discriminanting bebedourite types. These minerals appear isolated or in replacement textures as a response to changes in silica activity in the system (Fig. 1).

We subdivide the Salitre bebedourites into five varieties, on the basis of the dominant $\mathrm{Ca}$-Ti phase: (a) perovskite bebedourites are medium- to coarse-grained, and the only rocks where both olivine and perovskite are well preserved; (b) perovskite titanite melanite bebedourites are medium-grained, magnetite-poor, showing textural evidence of substitution of early perovskite by titanite, and of titanite by melanite; (c) titanite bebedourites occurring as rare thin dykes, are magnetite-poor and phlogopite-rich; (d) titanite melanite bebedourites, fine to medium-grained, contain similar amounts of titanite and melanite, either as independent crystals or showing replacement of early titanite by melanite; (e) melanite bebedourites, the commonest type, are medium- to coarse grained, often containing melanite phenocrysts.

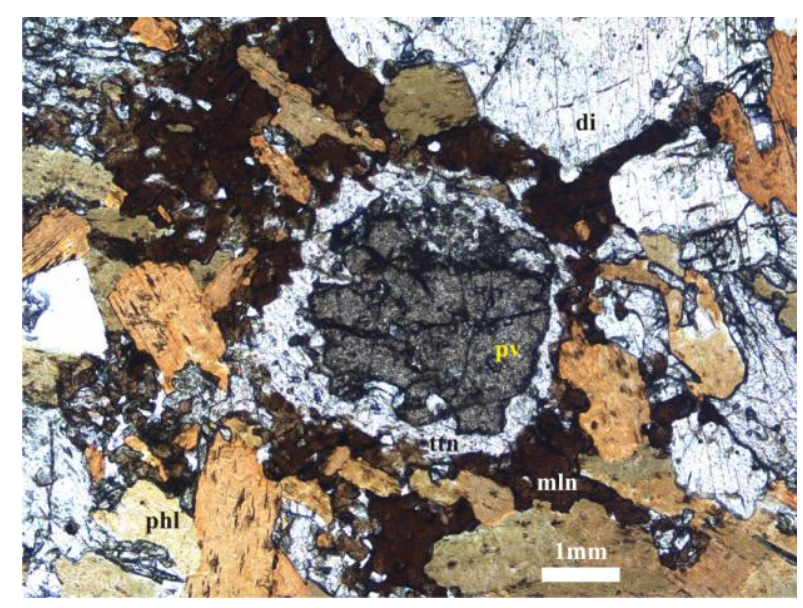

Fig. 1 Perovskite (pv) crystal rimmed initially by titanite (ttn) and later by melanite ( $\mathrm{mln})$.

\section{Mineral Chemistry}

The main mineral phases present in the Salitre bebedourites were analyzed with a CAMECA SX 50 electron microprobe at the University of Brasília.

Olivine is a relatively rare constituent in Salitre bebedourites, although abundant in other Salitre rock types, such as phoscorites and carbonatites. It was found in only two of the analyzed bebedourites, but may locally reach ca. 50 vol.\%. Fo content ranges from 83 to 87 mol.\%, comparable with olivine in similar rocks from the Tapira Complex in the APIP, but lower than olivine in parental phlogopite-picrites from that locality (Brod, 1999), suggesting that the bebedourites accumulated from slightly evolved ultramafic magma.

Clinopyroxene composition evolves along the Diopside-Hedenbergite series, showing small $\mathrm{Na}$ enrichment in the latest stages. Regardless of compositional overlap, it is clear that pyroxene with the highest contents of the diopside molecule $\left(\mathrm{Di}_{88-92}\right)$ are from the olivine-rich rocks. The next evolution stage is marked by pyroxene from perovskite bebedourites $\left(\mathrm{Di}_{77-90}\right)$, followed by those from perovskite-titanitemelanite bebedourites $\left(\mathrm{Di}_{69-88}\right)$, titanite bebedourites $\left(\mathrm{Di}_{61-84}\right)$, and titanite-melanite bebedourites $\left(\mathrm{Di}_{60-72}\right)$. 


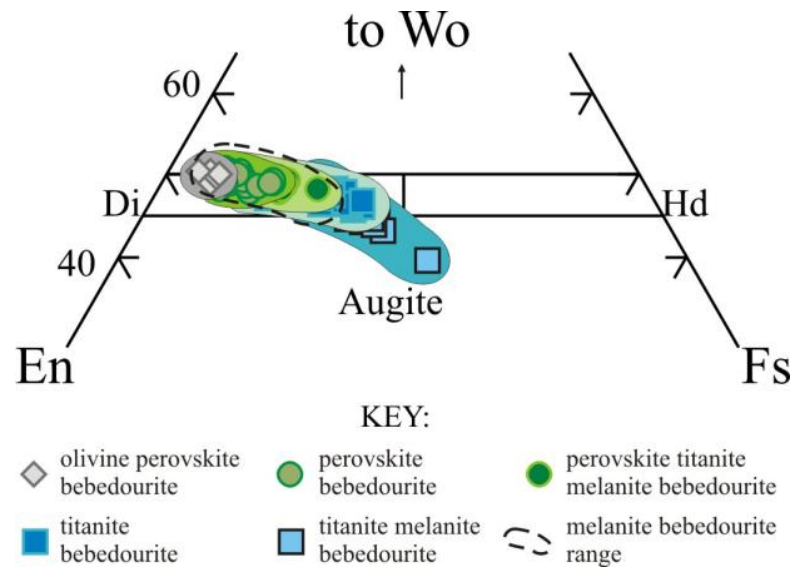

Fig. 2 Compositional variation of clinopyroxene in the Salitre bebedourites.

Therefore, changes in $\mathrm{Ca}-\mathrm{Ti}$ phases, from perovskite through titanite to melanite are accompanied by progressive increase in the Hedenbergite molecule in the pyroxene, consistent with magma evolution. However, bebedourites containing melanite as the sole $\mathrm{Ca}-\mathrm{Ti}$ phase, which were expected to be the most evolved, have diopside with intermediate composition $\left(\mathrm{Di}_{69-90}\right)$, overlapping the range of pyroxenes from perovskite bebedourites to titanite bebedourites.

Phlogopite evolves along the phlogopite-annite series, with a slight tendency to $\mathrm{Fe}^{3+}$ enrichment. The overall evolution accompanies the progressive $\mathrm{Si}$-enrichment of Ca-Ti minerals, except in the melanite bebedourites, where the mica has intermediate composition a behaviour similar to that observed in the pyroxene.

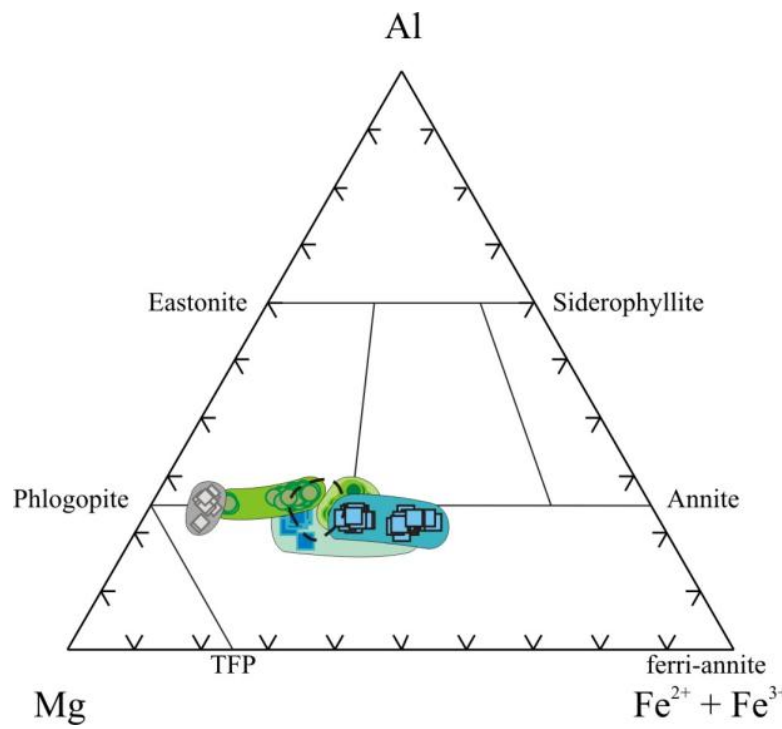

Fig. 3 Composition of phlogopite from the Salitre bebedourites. Symbols as in Fig. 2.

Phlogopite from each rock-type plot in a relatively restricted interval, although some overlap is observed. The compositional range is comparable to that of phlogopites in bebedourites from the Tapira Complex (Brod et al., 2001), but extends to lower magnesium contents. The increase in $\mathrm{Fe}^{2+} /\left(\mathrm{Fe}^{2+}+\mathrm{Mg}\right)$ is accompanied by increase in $\mathrm{Ti}$ and $\mathrm{Mn}$, and the most evolved micas are slightly depleted in Al.

Perovskite from the Salitre bebedourites show a restricted composition, near the ideal perovskite composition $\left(\mathrm{CaTiO}_{3}\right.$ molecule ranging from 91 to 98\%). Some REE substitution is in place, with the loparite molecule ranging from 1 to $8 \%$ ). Lueshite is up to $1.5 \mathrm{~mol} \%$ and the tausonite end-member is always lower than 1 mol.\%. These values are comparable with perovskites in bebedourites from the Tapira complex and from other ultrapotassic rocks such as kimberlites and kamafugites (Gravina et al., 2005; Mitchell 2003 and references therein). Some crystals are zoned, with a core slightly richer in the loparite molecule.

Titanite is usually an accessory, occuring either individually or as overgrowth rims on perovskite. Its composition is fairly uniform and does not discriminate well between bebedourite types $\mathrm{REE}_{2} \mathrm{O}_{3}+\mathrm{Y}_{2} \mathrm{O}_{3}$ reach up to 0.8 wt.\%, and $\mathrm{Fe}_{2} \mathrm{O}_{3}$ up to 2.6 wt.\%. Other possible traces, such as $\mathrm{Nb}$ and $\mathrm{Zr}$ were not analyzed.

Melanite garnet has variable but high $\mathrm{TiO}_{2}$ content (4 18 wt. \%). $\mathrm{ZrO}_{2}$ up to 2 wt. $\%$, and $\mathrm{REE}_{2} \mathrm{O}_{3}+\mathrm{Y}_{2} \mathrm{O}_{3}$ up to 0.35 wt. $\%$. Garnets from perovskite-titanite-melanite bebedourite and titanite-melanite bebedourite show a trend of magmatic evolution marked by an increase in $\mathrm{SiO}_{2}$ and $\mathrm{Fe}_{2} \mathrm{O}_{3}$, and decrease in $\mathrm{Al}_{2} \mathrm{O}_{3}, \mathrm{TiO}_{2}, \mathrm{FeO}$, and $\mathrm{MgO}$. However, garnets from melanite bebedourites do not fit this trend, being compositionally similar to the least-evolved varieties. Also, garnet in the melanite bebedourites shows a distinctive enrichment in $\mathrm{Al}_{2} \mathrm{O}_{3}$ relatively to garnets in other rocks.

\section{Whole-rock trace elements}

Average REE patterns for the various types of Salitre Bebedourites are given in Fig. 4.

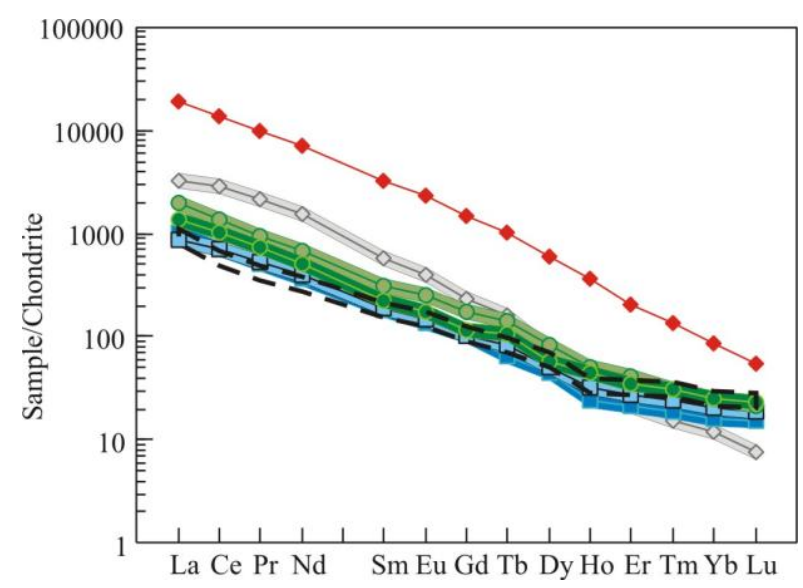

Fig. 4 REE patterns of Salitre bebedourites. Symbols as in Fig. 2. A perovskite analysis from the Tapira Complex (Brod, 1999) is plotted for comparison (red line). 
REE patterns are similar among diferent bebedourite types, with $\mathrm{Ce}_{\mathrm{N}} / \mathrm{Yb}_{\mathrm{N}}$ in the range 40-93, except for olivine- and perovskite rich samples, which show a strongly fractionated pattern $\left(\mathrm{Ce}_{\mathrm{N}} / \mathrm{Yb}_{\mathrm{N}}=240\right)$, probably a mineralogical effect of perovskite accumulation. Melanite bebedourites have the least fractionated REE $\left(\mathrm{Ce}_{\mathrm{N}} / \mathrm{Yb}_{\mathrm{N}}=26\right)$.

In chondrite-normalized trace element diagrams olivine-rich perovskite bebedourites have a positive spike at $\mathrm{Th}$, and negative spikes at $\mathrm{P}, \mathrm{Zr}$, and $\mathrm{Hf}$, which are also consistent with perovskite accumulation (Fig. $5)$.

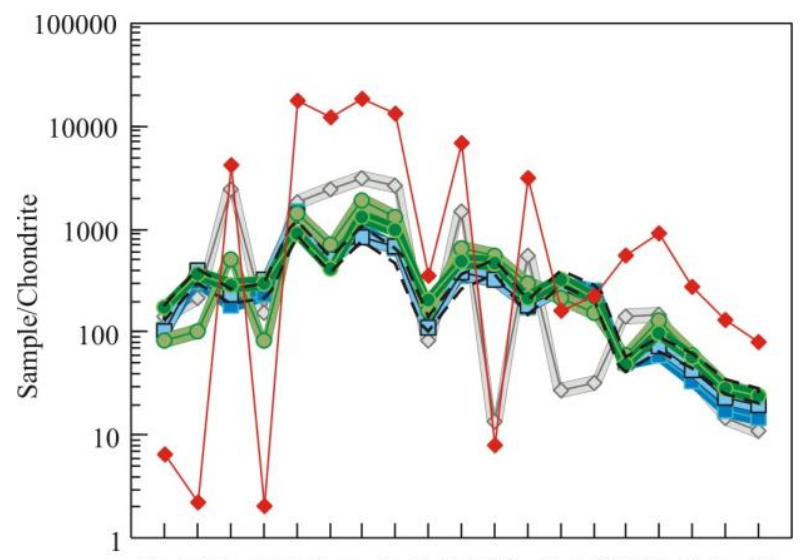

Ba RbTh K Nb TaLa Ce SrNd P SmZr Hf Ti Tb Y Tm Yb

Fig. 5 Trace-element diagrams for the Salitre bebedourites. Symbols as in Fig. 2. A perovskite analysis from the Tapira Complex (Brod, 1999) is plotted for comparison (red line).

$\mathrm{Nd}$ and $\mathrm{Sr}$ isotopic ratios show that Salitre bebedouritic magmas derived from a lithospheric mantle source similar to that of other APIP rocks. The composition of most analyzed samples is very close, but the sample of titanite melanite bebedourite has a slightly higher ${ }^{87} \mathrm{Sr} /{ }^{86} \mathrm{Sr}(\mathrm{i})$ (0.705670), for a similar $\varepsilon \mathrm{Nd}(\mathrm{t})(-6.99)$, suggesting that the $\mathrm{Si}$ content of $\mathrm{Ca}-\mathrm{Ti}$ minerals correlates to some extent with upper-crust assimilation. As noted for the mineral chemistry data, the melanite bebedourite does not fit the trend of the other samples, showing the highest $\varepsilon N d(t)\left(-5.02\right.$, for $a{ }^{87} \mathrm{Sr} /{ }^{86} \mathrm{Sr}(\mathrm{i})$ of 0.705167 .

Most Salitre bebedourites appear to have evolved by AFC, which induced changes in the assemblage of $\mathrm{Ca}$ Ti minerals. However, rocks where melanite is the sole $\mathrm{Ca}$-Ti phase seem to result from an independent, more siliceous but less contaminated magma, consistent with the mineral chemistry data and with the lesser degree of REE fractionation.

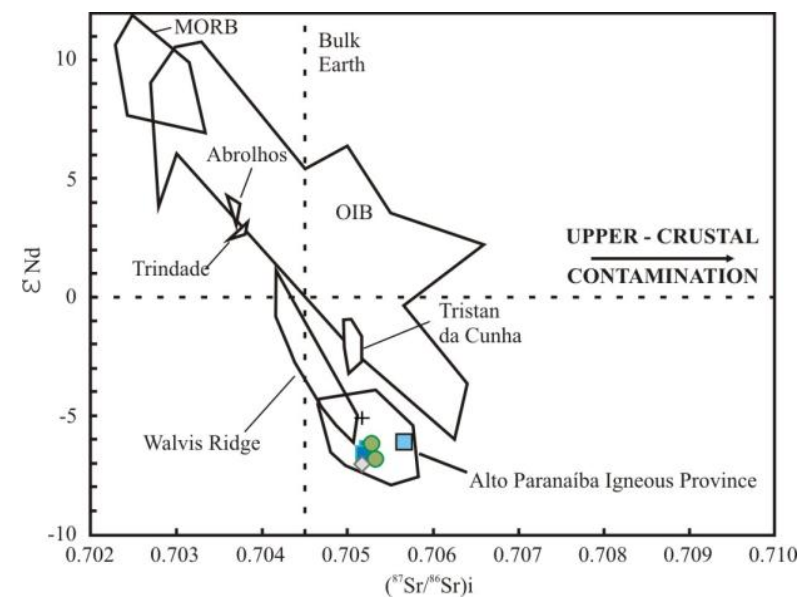

Fig. 6 Sr- and Nd-isotope composition of Salitre bebedourites. Symbols as in Fig. 2. Fields from Gibson et al. (1995).

\section{Acknowledgements}

This work was suported by Brazilian agencies CNPq and CAPES, and by the University of Brasília.

\section{References}

Brod J.A. 1999. Petrology and geochemistry of the Tapira alkaline complex, Minas Gerais State, Brazil. University of Durham, UK, PhD thesis.

Brod J.A., Gaspar J.C., Araújo D.P. Gibson S.A., Thompson R.N., Junqueira-Brod, T.C., 2001. Phlogopite and tetra-ferriphlogopite from Brazilian carbonatite complexes: petrogenetic constraints and implications for mineral-chemistry systematics. Journal of Southeast Asian Earth Sciences, 1, 265296.

Gibson, S.A., Thompson, R.N., Leonardos, O.H., Dickin, A. P., Mitchell, J.G., 1995. The late Cretaceous impact of the Trindade mantle plume: evidence from large - volume, mafic potassic magmatism in SE Brazil. Journal of Petrology, 36, 189-229.

Gravina, E.G. ; Brod, J. A. ; Gaspar, J.C. ; Fernandes, N.G.,2005. Uso de elementos menores em perovskita como indicadores de proveniência de sedimentos detríticos - implicações para a discriminação de rochas ultrapotássicas em províncias alcalinas . In: I Simpósio Brasileiro de Metalogenia, Gramado - RS. Resumos CD-ROM version, 1-4 (in Portuguese).

Le Maitre, R. W., 2002. Igneous Rocks: a Classification and Glossary of Terms: Recommendations of the International Union of Geological Sciences Subcommission on the Systematics of Igneous Rocks. Cambridge University Press, Cambridge, UK.

Mitchell, R. H., 2002. Perovskites: Modern and ancient. Almaz Press, Ontario, Canada.

Tröger E., 1928. Alkaligesteine aus der Serra do Salitre im westlichen Minas Geraes. Brasilien. Centralblatt für Mineralogie, Geologie und Paläontologie, Abt A: 202-204. 